УДК 332.1

\title{
ЕКОНОМІЧНИЙ АСПЕКТ ТЕРИТОРІАЛЬНОГО ВИРОБНИЦТВА АМАРАНТУ, КОНОПЛІ ТА СОРГО В УКРAÏHI
}

\section{ECONOMIC ASPECT OF TERRITORIAL PRODUCTION OF AMARANTH, HEMP AND SORGO IN UKRAINE}

\author{
Безугла Людмила Сергіївна \\ кандидат наук з державного управління, доцент, \\ Дніпровський державний аграрно-економічний університет \\ ORCID: https://orcid.org/0000-0002-6520-4325 \\ Bezuhla Liudmyla \\ Dnipro State Agrarian and Economic University
}

\begin{abstract}
В статті обґрунтовано доцільність виробництва амаранту, коноплі, та сорго на території України. Встановлено, що аномальні кліматичні умови в минулих сезонах змусили аграріїв звернути увагу на вирощування альтернативних посухостійких культур. Ідентифіковано потенціал сортів амаранту та його середню врожайність. 3 метою визначення достатності продукції на ринку України здійснено аналіз посівних площ амаранту. Досліджено стан галузі коноплярства в Україні та посівні площі технічної коноплі. Встановлено, що в світі переробляється 100\% рослини конопель, в той час коли в Україні - лише 85\%, решта вважається відходами. Розглянуто проблематику ринку коноплі в Україні. Проаналізовано посівні площі сорго в Україні, яке здебільшого вирощують в степовій зоні. Узагальнено, що стримуючим фактором розширення площі посівів сорго в інших зонах, є недостатня сума температурних показників упродовж вегетаційного періоду.
\end{abstract}

Ключові слова: економічний аналіз, виробництво, агропідприємства, амарант, конопля, сорго.

В статье обоснована целесообразность производства амаранта, конопли, и сорго на территории Украины. Аномальные климатические условия в прошлых сезонах заставили аграриев обратить внимание на выращивание альтернативных засухоустойчивых культур. Идентисрицировано потенциал сортов амаранта и его среднюю урожайность. С целью определения достаточности продукции на рынке Украины осуществлен анализ посевных площадей амаранта. Исследовано состояние отрасли коноплеводства в Украине и посевные площади технической конопли. Установлено, что в мире перерабатывается 100\% растений конопли, в то время как в Украине - всего 85\%, остальное считается отходами. Проанализированы посевные площади сорго в Украине, которое выращивают в степной зоне. Обобщено, что сдерживающим фрактором расширения площади посевов сорго в других зонах, является недостаточная сумма температурных показателей в течение вегетационного периода.

Ключевые слова: экономический анализ, производство, агропредприятия, амарант, конопля, сорго.

Abnormal climatic conditions in past seasons forced farmers to pay attention to the cultivation of alternative drought-resistant crops. The production of organic products becomes more and more relevant with each surveyed year due to the significant number of environmental, economic, and social benefits, as opposed to traditional agricultural production. It is worth noting that the intensive farming method, which is mainly used in the modern world, has a destructive effect on the environment, and also practically depletes natural resources, making them unsuitable for agricultural production. The article substantiates the feasibility of the production of amaranth, hemp, and sorghum on the territory of Ukraine. The potential of amaranth varieties and its average yield have been identified. In order to determine the sufficiency of products on the Ukrainian market, an analysis of the sown areas of amaranth was carried out. In the modern Ukrainian mass consciousness, hemp is firmly associated with a narcotic drug, while for a long time this plant has been processed on the territory of Ukraine as a food, fodder and industrial crop. The state of the cannabis industry in Ukraine and the acreage of industrial hemp were investigated. It has been established that $100 \%$ of hemp plants are processed in the world, while in Ukraine - only $85 \%$, the rest is considered waste. The acreage of industrial hemp in Ukraine tends to decrease, which in 2017 amounted to 2.8 thousand hectares, and in $2019-1.02$ thousand hectares. The area under crops of sorghum in Ukraine, which is grown in the steppe zone, has been analyzed. The sorghum harvesting area in 2017 was 71 thousand hectares, in $2018-41.9$ thousand hectares, 
in 2019 - 46.8 thousand hectares. The yield of sorghum was set in 2017 at the level of 27.9 centner per hectare, in 2018 - 46.3 centner per hectare, in 2019 - 40.8 centner per hectare. It is generalized that the limiting factor for the expansion of sorghum crops in other zones is the insufficient sum of temperature indicators during the growing season. Considering the natural-resource potential and the positive dynamics of the financial and economic indicators, Ukraine is on the way of development of production of amaranth, sorghum and hemp, and domestic producers can be competitive in the European markets.

Keywords: economic analysis, production, agricultural enterprises, amaranth, hemp, sorghum.

Постановка проблеми. Сучасний стан розвитку аграрного бізнесу в Україні перебуває в процесі трансорормації, який пояснюється спробами зменшити відставання в швидкості здійснення ринкових перетворень в порівнянні із іншими секторами економіки. Проведення маркетингових досліджень на ринку виробництва певних видів продукції дає змогу реально оцінити стан та перспективи їх подальшого розвитку. Виробництво органічної продукції 3 кожним досліджуваним роком стає все більш актуальним за рахунок значної кількості екологічних, економічних, а також соціальних переваг на противагу традиційному сільськогосподарському виробництву. Варто зауважити, що інтенсивний метод ведення сільського господарства, котрий переважно застосовується в сучасному світі, здійснює деструктивний вплив на навколишнє середовище, а також практично виснажує природні ресурси, перетворює їх на непридатні для ведення сільськогосподарського виробництва.

Ключова особливість землеробства України на сучасному етапі ґрунтується на виробництві продукції рослинництва при обмежених витратах антропогенної енергії і збереженні довкілля від процесів деградації та забруднення. Вирішення цієї проблеми можливе шляхом упровадження нових та малопоширених кормових, овочевих, зернових і лікарських рослин, агроценози яких завдяки значному адаптивному потенціалу забезпечують високий рівень реалізації продуктивності при мінімальних енергетичних витратах і здійснюють позитивний біогеоценотичний вплив на елементи родючості ґрунту. Враховуючи вищенаведене наголосимо на тому, що проблематика дослідження ринків виробництва амаранту, коноплі та сорго в сучасних умовах господарювання набуває надзвичайної актуальності та вимагає постійних наукових досліджень.

Аналіз останніх досліджень і публікацій. Дослідженням ринків виробництва амаранту, коноплі, сорго, а також аналізом даних ринків в своїх наукових працях приділяють увагу такі вітчизняні та закордонні науковці як: Boutin A., Johnson Renée, Марченко Ж. Ю., Дуда О. М., Примаков О. А., Маринченко І. О., Миколенко С. Ю., Захаренко А. А. та ін.
Формулювання цілей статті. Метою статті виступає процес проведення економічного аналізу щодо виробництва амаранту, коноплі та сорго, а також визначення ключових тенденцій їх розвитку.

Виклад основного матеріалу дослідження. Есрективне та раціональне застосування рослинних ресурсів - одна із найактуальніших проблем сучасності. Шляхом використання нових та модернізованих рослин з'являється можливість вирішення певних проблем сільськогосподарського виробництва, ключовою з яких виступає проблема дефіциту білка. До таких рослин відноситься амарант «містичне зерно ацтеків», який протягом тисячоліть був годувальником стародавніх цивілізацій американського континенту - інків і ацтеків [1, с. 413].

Щорічні аномальні кліматичні умови надзвичайно бентежать вітчизняних аграріїв і примушують їх акцентувати увагу на вирощуванні альтернативних культур. Альтернативним варіантом збереження врожаю в складних посушливих умовах стає включення до сівозміни агропідприємств перспективних посухостійких культур, де в першу чергу такою культурою являється амарант.

Як зазначає Олександр Дуда, голова Асоціації виробників амаранту і амарантової продукції: «середня врожайність амаранту становить близько 2 т/га, однак цей показник не $є$ найвищою врожайністю цієї культури. Потенціал сортів розрахований на 4 т насіння 3 гектара. Україна може стати найбільшим виробником амаранту в світі. Собівартість вирощування цієї культури в Україні складає \$400/га» [2].

За даними Інтернет-видання Agroday: «В Україні в 2017 році площа посівів амаранту становила 250 га, в 2018 році - 800 га. В 2019 близько 4 тис. га, а в 2020 році прогнозувалося її зростання до 20 тис. га. Причиною такого інтересу до амаранту став швидко зростаючий світовий ринок цієї культури, на якому перші отримують максимальні доходи. Тільки амарантової олії в світі продається на $\$ 0,5$ млрд, а попит на неї зростає приблизно на $12 \%$ в рік. До речі, українські підприємці налагодили виробництво унікальної олії амаранту холодного віджиму, в якому корисні 
речовини цієї чудо-рослини зберігаються практично повністю. Також в 2019 році до існуючих 30 агропідприємств, які займалися вирощуванням амаранту, додалися ще 100. При цьому тридцять компаній диференціювали сореру своєї діяльності та зайнялися виробництвом амарантової олії, борошна, крупи, пластівців та іншої продукції з цієї рослини» $[2,10]$.

У масовій свідомості сучасних українців, конопля міцно асоціюється з наркотичним засобом, тоді як здавна ця рослина обробляється на території України в якості харчової, кормової та технічної культури. 3 насіння конопель виготовляють цінну олію, а з шроту - продукти харчування для худоби. 3 конопляного волокна виробляють екологічний текстиль, багаття йде на постілку тваринам, мульчу для рослин і навіть на виготовлення будівельних матеріалів.

Марченко Ж. Ю. Примаков О. А., Маринченко І. О. зазначають, що: «коноплярство $€$ стратегічною галуззю суспільства у світовому масштабі. Воно продукує сировинний матеріал не лише для текстильної промисловості (одягу, канатів, шпагату, мотузок тощо), а й створює стратегічно важливу сировину, що використовується в багатьох сорерах економіки: солома, треста, волокно - у виготовленні композитів, нетканих матеріалів, геотекстилю, що застосовуються в різних галузях виробництва; костра - в меблевій промисловості, у виготовленні паливних пелетів, композиційних матеріалів; конопляна олія у фрармацевтичній та харчовій промисловості, у виробництві косметики» [3, с. 160].

Також важливо зазначити, що вирощування конопель успішно може замінити частину лісових насаджень для виробництва паперу, який має значно вищі показники щодо міцності та зносостійкості та набагато дешевший за традиційний папір з деревинної целюлози. 3 одного гектара конопель підприємці отримують шість тонн целюлози в рік, а це значно більше, ніж річний приріст одного гектару лісу. Дерева ростуть десятиліттями, а врожай конопель можна зібрати вже через 120 днів після сівби. Для вирощування лісу потрібні великі ділянки землі, конопля ж може зростати практично скрізь [4, с. 145].

У світі переробляється $100 \%$ рослини конопель, тоді як в Україні - лише 85\%, решта вважається відходами. Через недосконалість законодавства українські виробники можуть працювати лише з насінням і волокном. Листя та суцвіття технічних конопель не використовують, хоча у світі їх застосовують у фармакології, косметології та харчовій промисловості. Важливою складовою $€$ те, що коноплі біо- логічно сумісні з усіма вирощуваними культурами, яким не потрібні добрива [5].

Незважаючи на багатий попередній досвід вирощування і переробки цієї культури, в даний час ринок технічних конопель в Україні перебуває в занепаді. За інформацією порталу Agravery.com: «Площа посівів технічних конопель скоротилася в 2018 році відразу на 60,7\% в порівнянні з 2017 роком, продовжилася негативна тенденція і в 2019 році. Моніторинг ринку технічних конопель показує, що головними негативними фракторами впливу на нього є: необхідність отримання ліцензії; відсутність сучасних потужностей з переробки конопляної сировини; низька платоспроможність населення. Динаміку посівних площ технічних конопель в Україні представлено на рис. 1.

За даними рисунку 1 видно, що посівні площі технічних конопель в Україні мають тенденцію до зменшення, які у 2017 році становили 2,8 тис. га, а у 2019 - 1,02 тис. га. Рівняння параболічного тренду більш чітко відображає тенденцію зміни посівних площ технічних конопель, про що свідчить рівень коефріцієнта апроксимації який дорівнює 1.

Впроваджуючи коноплі в сівозміну, можна збільшити виробництво кормових культур, поліпшити родючість ґрунту та вносити набагато меншу кількість добрив. Серед ідеальних рослин сусідів для конопель цукрові буряки, картопля, силосна кукурудза, озимі культури, люпин і конюшина [5]. Основним напрямком бізнесу на ринку технічних конопель $€$ виробництво насіння на експорт. Інша продукція 3 конопель перебуває в категорії нішевої і не витримує конкуренції з масовим сегментом. Наприклад, конопляна олія користується обмеженим попитом у послідовників здорового способу життя, і не може конкурувати за ціною з соняшниковою» - пояснюють аналітики [6].

Проаналізувавши ринок технічних конопель в Україні варто зазначити, що перспективи його розвитку тісно пов'язані із збільшенням сегменту органічного виробництва та попиту на продукцію в світі. У вітчизняних коноплярів $€$ перспективи збільшення поставки насіння, масла та волокна на ринки платоспроможні Європейського союзу, а також інших країн світу. За умов створення стабільних реалізаційних каналів продуктів коноплярства, стане економічно вигідним створення в Україні відповідних переробних підприємств [9].

Під впливом зміни клімату сорго набуває більшої популярності в Україні. Якщо раніше до цієї культури відносилися як до джерела зеленої маси, необхідної для забезпечення 


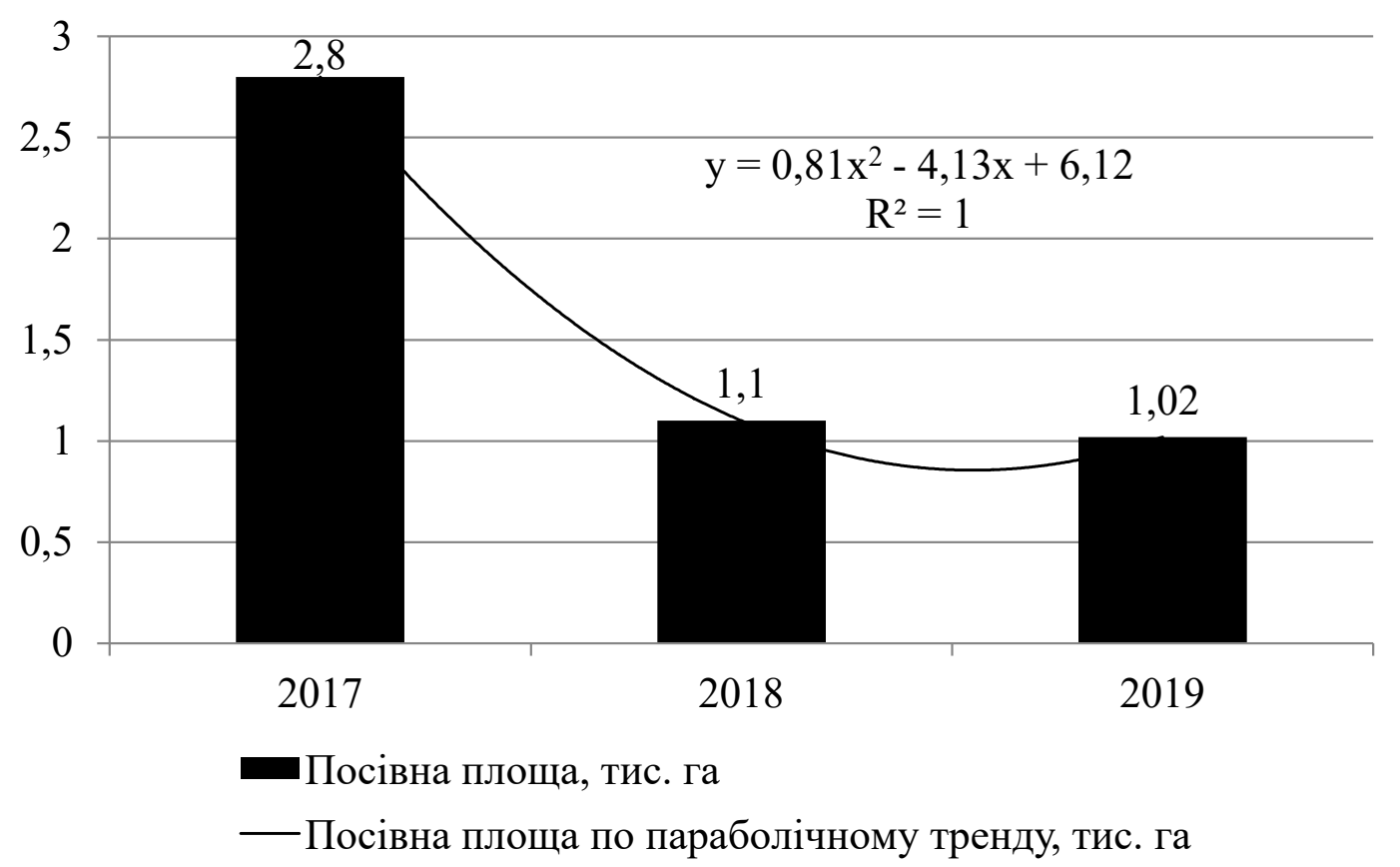

Рис. 1. Аналітичне вирівнювання посівних площ технічних конопель в Україні, тис. га

Джерело: побудовано за [6]

потреб тваринництва, то наразі нею зацікавилися виробники зерна. Позитивна тенденція у вирощуванні сорго спостерігається і в світі.

В Україні рід сорго представлений культурними однорічними видами: сорго звичайне, джугара, гаолян, суданська трава. Їх вирощують для забезпечення кормових, технічних та продовольчих потреб. За характером використання розрізняють сорго цукрове, стебла якого застосовують для виробництва патоки, сиропу, силосу; віничне, з волотей якого виготовляють віники та щітки; кормове - для зеленого корму та сіна; зернове - для виробництва круп, борошна, крохмалю, спирту, комбікорму тощо.

Сорго в Україні здебільшого вирощують в степовій зоні. Стримуючими фракторами розширення площі посівів сорго в інших зонах, $\epsilon$ недостатня сума ефрективних температур упродовж вегетаційного періоду. Рекордний урожай сорго, який досяг майже 234 тис. т, вітчизняні аграрії отримали у 2016 році. На це вплинуло розширення посівної площі та понад двотонний рівень урожайності зерна. Після цього відбулося суттєве зменшення виробництва (рис. 2).

Площа збирання сорго у 2017 році становила - 71 тис. га, у 2018 - 41,9 тис. га, у $2019-$ 46,8 тис. га. Урожайність сорго встановлена 2017 році на рівні 27,9 ц/га, у 2018 - 46,3 ц/га, у 2019 - 40,8 ц/га. Обсяг виробництва сорго зафріксовано у 2017 році - 1985,0 тис. ц, у 2018 - 1939,8 тис. ц, у 2019 - 1920,3 тис. ц.
Аналізуючи інформацію надану порталом «Agro-business» наголосимо на тому, що: «сорго є перспективною культурою для України. Силосне сорго здатне задовольняти потреби тваринництва у високоякісному силосі та зеленій масі. Зернове сорго є відмінною альтернативою ячменю, кукурудзі, соняшнику в умовах посушливого клімату Півдня й Сходу України та здатне забезпечувати стійкі високі врожаї» [9].

Висновки. Підводячи підсумки проведеного дослідження варто наголосити на тому, що виробництво амаранту, коноплі та сорго в сучасних умовах кліматичних перетворень в Україні набуває надзвичайної актуальності. Враховуючи природно-ресурсний потенціал і позитивну динаміку фрінансово-економічних показників, Україна перебуває на шляху розвитку виробництва даних культур, а вітчизняні виробники можуть бути конкурентоспроможними на європейських ранках. Значною перешкодою на шляху розвитку та стимулювання екологічного напряму виробництва виступає низький рівень державної підтримки, переважно в частині екологічного законодавства, а також не менш важливим $€$ те, що державну підтримку отримують великі товаровиробники, а не дрібні та середні суб'єкти господарювання. Подальші дослідження спрямовані на проведення маркетингового аналізу щодо використання та корисності вирощування амаранту, коноплі та сорго в Україні. 


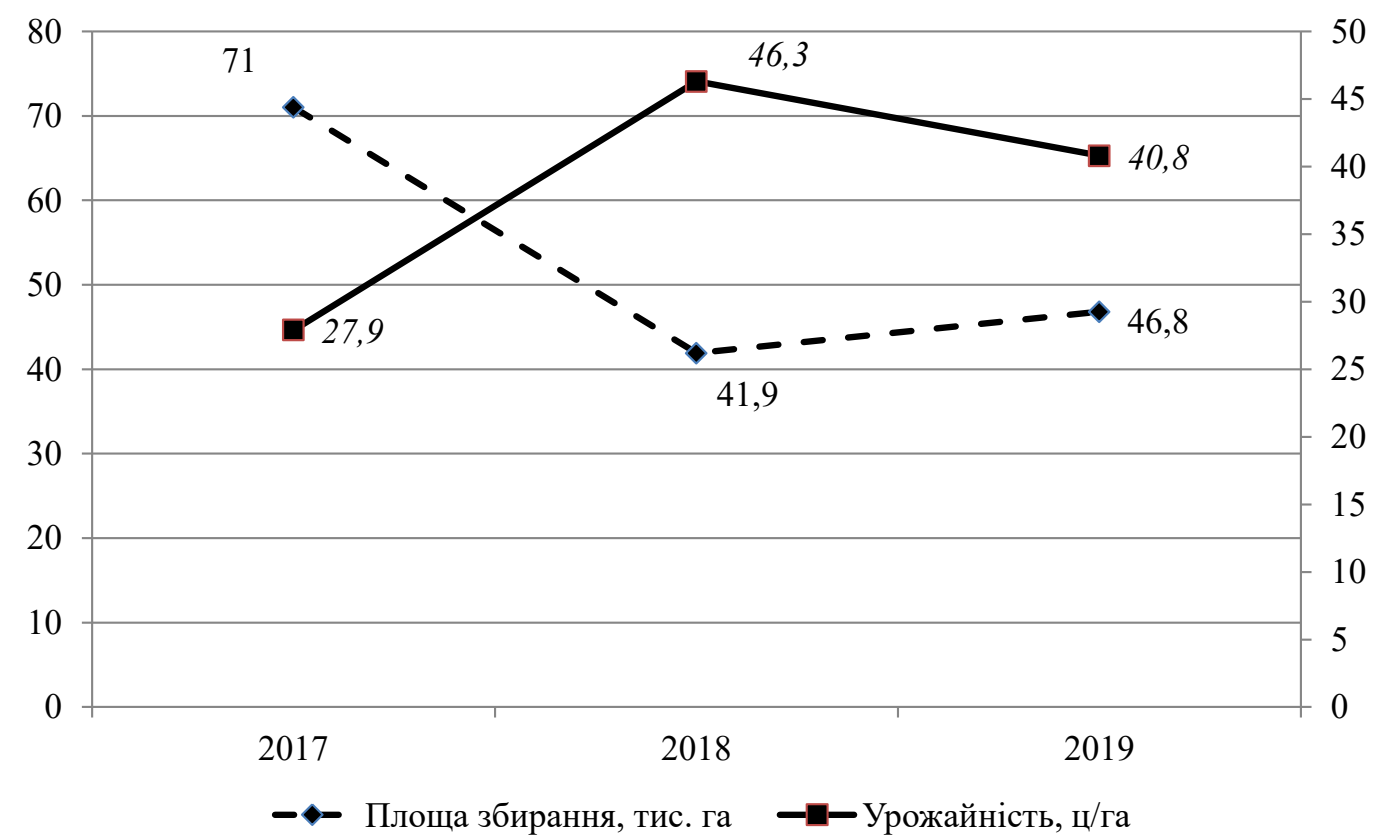

Рис. 2. Динаміка зібраних площ та урожайності сорго в Україні

Джерело: побудовано за [6]

\section{СПИСОК ВИКОРИСТАНИХ ДЖЕРЕЛ:}

1. Boutin A. Sur la presence d'une proportion considerable de nitre dans L' Amaranthus blitum. Comp. Rend. 1873. V. 76. P. 413-417.

2. Амарантова хвиля: в Україні зростають площі під посівами амаранту. URL: https:/lagroday.com.ua/2019/10/30/ amarantova-hvylya-v-ukrayini-zrostayut-ploshhi-pid-posivamy-amaratnu/ (дата звернення: 06.02.2021).

3. Марченко Ж. Ю. Напрями використання коноплепродукції у світі. Луб'яні та технічні культури : зб. наук. пр. Суми : ВД «Еллада». 2015. Вип. 4(9). С. 159-166.

4. Примаков О. А., Маринченко І. О. Технічні коноплі - перспективи розвитку культури. Технічні культури: інноваційні напрями досліджень : матеріали наук.-практ. конфр. молодих вчених (Глухів, 17-19 жовт. 2012 р.) / ДСЛК ІСГ Північного Сходу НААН. Харків : ПП «Озеров», 2013. С. 145-150.

5. Johnson Renée Hempasan Agricultural Commodity. Congressional Research Service. March 10, 2017. Congressional Research Digital Collection. URL: https://fas.org/sgp/crs/misc/RL32725.pdf (дата звернення: 05.02.2021).

6. В Україні площі посівів технічних конопель продовжують зменшуватися. URL: https://agravery.com/uk/ posts/show/v-ukraini-plosi-posiviv-tehnicnih-konopel-prodovzuut-zmensuvatisa (дата звернення: 04.02.2021).

7. Державна служба статистики України. Сільське господарство України за 2017, 2018, 2019 роки. URL: http://www.ukrstat.gov.ua/

8. Застрожніков А. Г., Застрожнікова І.В. Місце і роль фрермерських господарств в системі агробізнесу. Збірник наукових праць Таврійського державного агротехнологічного університету (економічні науки). Мелітополь : Люкс, 2010. № 2. С. 106-116.

9. Ринок сорго в Україні та світі. Агробізнес Сьогодні : веб-сайт. URL: http://agro-business.com.ua/agro/ ekonomichnyi-hektar/item/7839-rynok-sorho-v-ukraini-ta-sviti.html (дата звернення: 05.02.2021).

10. Миколенко С. Ю., Захаренко А. А. Дослідження впливу амарантового та льняного борошна на якість печива. Технічні науки та технології. 2020. № 1(19). С. 228-240.

\section{REFERENCES:}

1. Boutin A. (1873) Sur la presence d'une proportion considerable de nitre dans L' Amaranthus blitum. Comp. Rend., v. 76, pp. 413-417.

2. Amarantova khvylja: $v$ Ukrajini zrostajutj ploshhi pid posivamy amarantu [Amaranth wave: in Ukraine the areas under amaranth crops are growing]. Retrieved from: https://agroday.com.ua/2019/10/30/amarantovahvylya-v-ukrayini-zrostayut-ploshhi-pid-posivamy-amaratnu/ (in Ukrainian) 
3. Marchenko, Zh. Ju. (2015). Naprjamy vykorystannja konopleprodukciji u sviti [Areas of use of hemp products in the world]. Lub'jani ta tekhnichni kuljtury-Bast and technical crops: a collection of scientific papers, 4(9), 159-166. (in Ukrainian)

4. Prymakov, O. A. \& Marynchenko, I. O. (2013). Tekhnichni konopli - perspektyvy rozvytku kuljtury [Technical hemp - prospects for cultural development]. Proceedings of the Materialy nauk.-prakt. konf. molodykh vchenykh (Ghlukhiv, 17-19 zhovt. 2012 r.), Kharkiv: DSLK ISGh Pivnichnogho Skhodu NAAN, pp. 145-150. (in Ukrainian)

5. Johnson Renée (2017). Hempasan Agricultural Commodity Congressional Research Service. Retrieved from: https://fas.org/sgp/crs/misc/RL32725.pdf

6. V Ukrajini ploshhi posiviv tekhnichnykh konopelj prodovzhujutj zmenshuvatysja [In Ukraine, the area under technical hemp continues to decline]. Retrieved from: https://agravery.com/uk/posts/show/v-ukraini-plosi-posivivtehnicnih-konopel-prodovzuut-zmensuvatisa (in Ukrainian)

7. Derzhavna sluzhba statystyky Ukrainy (2020). Siljsjke ghospodarstvo Ukrainy v 2017, 2018, 2019 rokakh [Agriculture of Ukraine in 2017, 2018, 2019]. Retrieved from: http://www.ukrstat.gov.ua/ (in Ukrainian)

8. Zastrozhnikov, A. H. \& Zastrozhnikova, I.V. (2010). Mistse i rol' fermers'kykh hospodarstv v systemi ahrobiznesu [The place and role of farms in the agribusiness system]. Zbirnyk naukovykh prats' Tavrijs'koho derzhavnoho ahrotekhnolohichnoho universytetu (ekonomichni nauky) - Collection of scientific works of the Tavriya State Agrotechnological University (economic sciences), 2, 106-116. (in Ukrainian)

9. Rynok sorgho $v$ Ukrajini ta sviti [Sorghum market in Ukraine and the world]. Retrieved from: http://agro-business.com.ua/agro/ekonomichnyi-hektar/item/7839-rynok-sorho-v-ukraini-ta-sviti.html (in Ukrainian)

10. Mykolenko, S. Yu. \& Zakharenko, A. A. (2020). Doslidzhennia vplyvu amarantovoho ta I'nianoho boroshna na iakist' pechyva [Investigation of amaranth and flax flour on the quality of biscuits]. Tekhnichni nauky ta tekhnolohii Technical sciences and technologies, 1(19), 228-240. (in Ukrainian) 